\title{
Central Bank Challenges after the Financial Crisis
}

\author{
Per H. Vale ${ }^{1, *}$ \\ ${ }^{1}$ NMBU School of Economics, Norwegian University of Life Sciences (NMBU), Aas, Norway \\ *Correspondence: NMBU School of Economics, Norwegian University of Life Sciences (NMBU), Aas, Postbox \\ 5003, NO-1432 Ås, Norway. Tel: 47-6496-5675. E-mail: per.vale@nmbu.no
}

Received: January 2, 2014

Accepted: May 12, 2014

Online Published: May 27, 2014

doi:10.5430/mos.v1n2p67

URL: http://dx.doi.org/10.5430/mos.v1n2p67

\begin{abstract}
s
This paper challenges monetary policy after the financial crisis. The discussion shows that forward guidance of the interest rate and Quantitative Easing (QE) may give monetary policy more power when the short term nominal interest rate is close to zero lower bound. The current recession is a consequence of excessive debt in private and public sector, and since both public and household sector need time to pay down debts and rebuild savings, standard monetary policy as well as non-standard monetary policy (QE) will have limited effects on the present recession. An important lesson from financial crisis is that imbalances in the financial sector and high debt in private and public sector may fly under the inflation radar screen in conventional monetary policy and undermine the economy. Monetary policy in future should therefore target also financial stability. Taylor's rule affords a monetary policy with maximum of transparency, but it is unlikely to perform better than a central bank's carefully judgment of inflation, production gap, other possible targets, and the means that the bank has available (the interest rate). The Tinbergen rule tells us that we need one instrument for every independent target, and monetary policy therefore needs help from other economic policy areas. Even if we need an independent central bank, the central bank must also communicate and cooperate with government. Finely, the paper suggests that one should use market mechanisms to a higher degree in the bank market to make clear to lending institutions that they are responsible and must consider the risk in relation to their investments.
\end{abstract}

Keywords: monetary policy; central bank policy; economic policy; financial crisis

\section{Introduction.}

Monetary policy in most countries today is under pressure. During the financial crisis - and in the years following many central banks pushed the short-term nominal interest rates down to zero. Since banks can hold currency for cheap money instead of depositing it in the central bank, short term nominal interest rates cannot go much below zero. This limits the effectiveness of monetary policy today.

This paper focuses on how to give more power to monetary policy, how to get financial stability and more effective monetary transmission mechanism, how to deal with economic bubbles etc. The approach is broad and many central bank questions coming to the surface after the financial crises is discussed.

The paper is organized in the following way: Chapter 2 briefly explain the financial crisis, chapter 3 describes conventional monetary policy and specifies the central bank challenges to day, chapter 4 discuses how to meet the different challenges. Chapter 5 summarizes the most important conclusions.

\section{What Happened During the Financial Crisis?}

To understand the problems coming to the surface in connection to the financial crisis, we must remind us selves of what was the financial crisis. The essential conditions behind the crisis were: 1) The underestimation of risk related to newly issued assets (subprime), 2) the opacity of the derived securities on the balance sheets of financial institutions (securitization), 3) the connectedness between the financial institutions (globalization), and 4) the collapse of the interbank market (the financial system), see Blanchard (2009). Much of the literature so far about the financial crisis agrees about these four points; see for example Bean et al. (2010), Brunnermeier (2009), and 
Claessens et al. (2008).

The crisis started in the United States. It was triggered by the increase in the interest rate in 2005 - 2006 (see figure 1), which resulted in a wave of defaults by many borrowers and a bursting housing bubble. The losses in sub-prime related obligations (SRO), which were owned by financial institutions the world around, increased dramatically. Some banks had too many loss-making loans relative to their equity. Those banks and other financial institutions then either financed themselves in the money market or they had to sell assets. The price of the assets then decreased and the actual value in some cases became less than their assessed value. This in turn reduced the banks' equity. In other banks the main problem was a major mistrust in the market that resulted in many depositors withdrawing their savings. These banks also tried to raise money by wholesale funding or selling assets. When the financial market observed that the government let large banks fail (such as Lehman Brothers), increased uncertainty spread with two decisive consequences: i) The interbank interest rate greatly increased, and ii) The amount one bank was willing to lend to other banks decreased, increasing the interest rate even more. This process culminated with collapse in the interbank market. We had a worldwide banking crisis.

One should neither overlook the responsibility for the crisis of weak financial regulation, lax bank supervision, and the market's under pricing of credit risk.

Today we know that the financial crisis developed into a world wide banking crisis which threatened to paralyze manufacturing companies important to the real economy; and after some time we had a world wide crisis in real economy (Brunnermeier, 2009).

\section{Central Bank Challenges}

\subsection{Conventional Monetary Policy}

I originally intended to focus on the situation for small and open countries. It became clear in the course of research, however, that many of the pressing problems are common to other countries and problems for large economic countries and unions can be recognized in similar problems for small open economies. Two of these joint problem of large and small economies relate to setting targets and choosing instruments to be used in their monetary policy.

\subsubsection{Targets in Conventional Monetary Policy}

\subsubsection{Inflation Targeting}

Inflation targeting is an economic policy in which a central bank makes public an inflation rate target, and then attempts to steer actual inflation towards the target through the use of interest rate changes and other monetary tools. The background for the change to having an inflation target from the 1990s was the high inflation in the 1970s to 80s, up to $15-16 \%$ per year, and the unstable macro economy in many countries in those years (Barro and Gordon, 1983). Subsequently, a consensus has been developed in favor of low and stable inflation. According to Greenspan low and stable inflation is a yearly inflation so low that expectations of change do not become a major factor in key economic decisions (Greenspan, 1989). New Zealand was the first country announcing a stable annual inflation target at the end of the 1980s. Other countries followed its lead shortly thereafter. Most countries today have quantified low and stable inflation as $2 \%$ yearly inflation.

\subsubsection{High Growth and Low Employment}

Most central banks want to contribute to a good utilization of their country's resources, including the labor forces. An important concept is the production potential, which means the highest level of real gross domestic product that can be sustained over the long term. The difference between the production potential and current production is the production gap. A central target in conventional monetary policy has been minimization of the production gap (Blanchard et al., 2010).

\subsubsection{Stable Exchange Rates}

Central banks in small and open economies often target their exchange rate against the currency of an important trade partner to meet their final target of price stability and the production target.

\subsubsection{Financial Stability}

Since financial stability is necessary for price stability and full employment, the central bank should also work for financial stability. However, many central banks thought the capital markets to be efficients. 


\subsubsection{The Instruments in Monetary Policy}

The most important tool in traditional monetary policy is the decision the central bank takes about the steering rate, i.e. the interest rate the banking sector obtains on their account in the central bank, which is a short term interest account. Through arbitrage the steering rate becomes tied to the interest rate in the short money market. The central bank can also issue statements that may impact the interest rate beyond the horizon of the short term interest decision.

Since the number of tools available in traditional monetary policy is limited, the central bank or government must prioritize and decide which targets - the inflation target, the production target or another target - should be most important.

Optimal tradional monetary policy has been perceived to determine an interest rate that makes a trade-off between the inflation gap and the production gap (Taylor, 1993 and 1999). Conventional thinking proposes that lower interest rates will encourage households to save less and consume more, and will encourage companies to invest more. In both cases, spending has increased, and if there is unemployment in the country, production and employment will increase. We recognize the Keynesian perspective, which avers that it seems appropriate to support the level of spending when the national product is less than potential production, and there is involuntary unemployment. In other situations, such as an overheated economy where there is little unemployment and wage rates are increasing significantly (as with inflation), the central bank should put the brakes on. One possibility here is to reduce demand by increasing the interest rate.

In standard monetary policy, capital markets are generally assumed to be efficient. Eventual financial imperfections and their potential macroeconomic effects are usually not taken into account when monetary policy is developed (Weber, 2011). Temporary inefficiencies, such as asset price and housing price bubbles, are deemed events that monetary policy can do little to counteract.

In the wake of the financial crisis and its new challenges, some central banks have developed non-standard monetary policy measures, such as interest rates below zero and quantitative easing. This paper will discuss these and other means later.

\subsection{During the Financial Crisis Interest Rate Reached the Lower Bound}

According to the theory above, interest rates in the U.S. and in other countries were pushed down in the first years of the new century in order to fight the recession after the attack on the Twin Towers, see figure 1. We must go back to the 1950s to find as low an interest rate in the U.S.A. The U.S. Federal Reserve (Fed) continued to keep the interest rate low in the following years to stimulate the growth of employment. In the years 2004 to 2005 the Fed increased the interest rate as the economic situation became normalized. Then came the financial crisis in 2007/2008, and central banks in the U.S. and other countries dramatically decreased their interest rates.

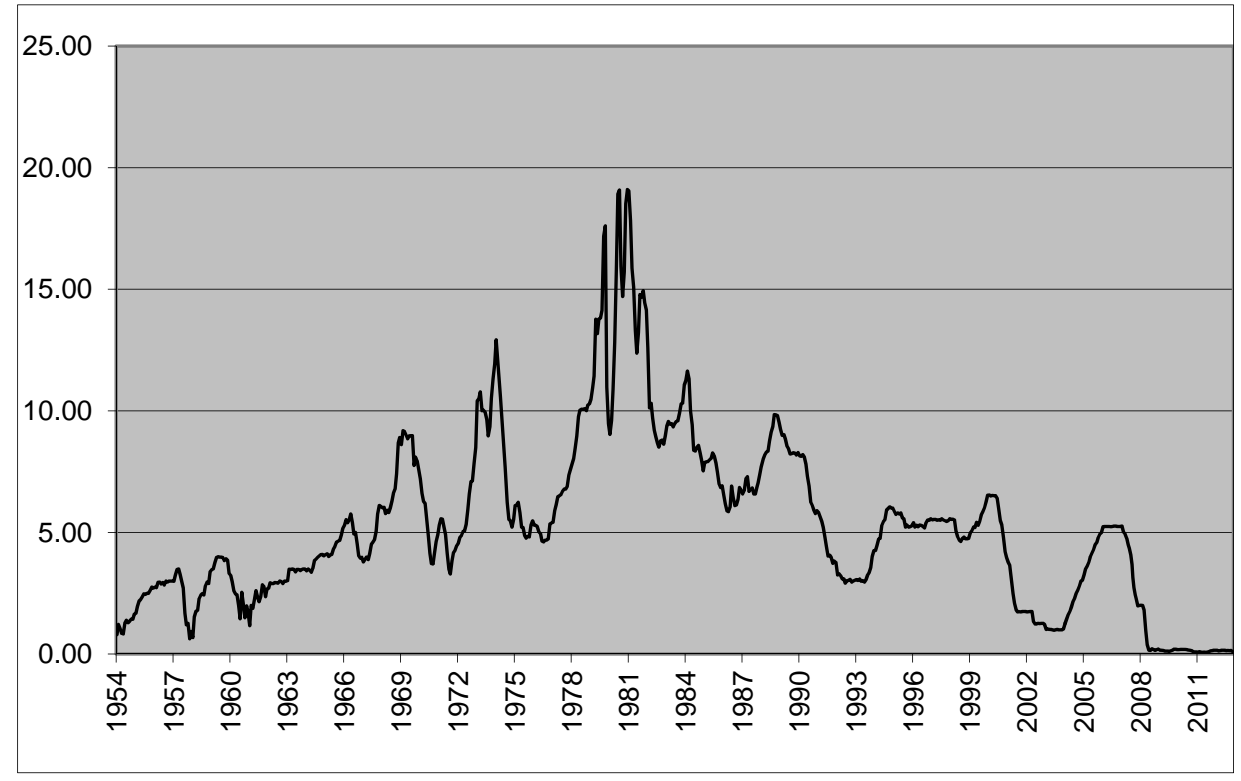

Figure 1. Federal Funds Rate (Effective) in the Period July 1954 to July 2013. Source: U.S. Federal Reserve 
As previously explained, when interest rates approached zero, the central banks were not prepared to cut the interest rate below zero. Then traditional monetary policy came to an effective end. To continue the struggle against an undesirable economic situation after the outbreak of the financial crisis, many countries pursued an expansive fiscal policy that included large deficits in public budgets. In some cases these deficits came on top of significant accumulated deficits from the past resulting in large government debts in some countries. These imbalances required these governments to change an expansive policy to a consolidation strategy in their fiscal policies (Reinhart and Rogoff, 2009), and the problems of stagnant production and a high unemployment rate continued.

\subsection{Challenges for Central Banks}

\subsubsection{To Give Power to Monetary Policy}

Both Keynes (1936), Vickrey (1955), Phelps (1972) and Summers (1991). warned about the problem for monetary policy when the short term nominal interest rate is close to zero. To come around the problem a few central banks have the last years decided on an interest rate below zero. Examples include Japan and Denmark. However, their experiences are too uncertain to draw any general conclusions. Other central banks state that a negative interest rate is an extraordinary step to take which must be thought through carefully, and that time has not come (Richards, 2013).

Another mean some central banks have tried to come around the problem is so-called "Easy monetary policy". Easy monetary policy is that the central bank prints money and buys financial assets of longer maturity and in this way try to make it cheaper for borrowers to have access to long term financing. We will ask if this approach will increase the power of monetary policy, and what about the border spill over? For more details, see section 4.1.2.

We will also make comments to a new trend in monetary policy, namely central banks guidance of the interest rate in the future. In this way the central banks hope to influence the expectations about the short term interest rate in a predictable future. We will ask if this is another way to give more power to monetary policy.

Notice, economic literature explains that when the monetary authority faces a zero lower bound on the nominal interest rate, it should be optimal to plan for a temporary period of higher inflation rate, see for example Eggertsson and Woodford (2003). However, in U.S. and Europe many politicians, governments and central banks are frightening higher inflation rate. They might therefore be negative to printing money which easy monetary policy also can be said to be.

\subsubsection{Financial Stability}

Due to a dysfunctional financial market many banks today give priority to restructuring their balance sheet, rather than continuing to provide lending to the private sector. The consequences are fewer realized investment projects, which again hamper economic development. Further, over-indebted households and firms appear to increase their savings in order to repair their balance sheets, and thus are less inclined to borrow for consumption and investment purposes. This also makes the monetary transmission mechanism less effective today.

The dysfunctional financial market today is also related to destabilizing imbalances in trade. Germany, Japan, China, oil-producing countries and some other countries have large trade surpluses. Other nations, for example the U.S., some western European countries, and some less developed economies have great trade deficits. A country with trade deficits over many years not driven by domestic investments is facing nothing else than a rise in foreign debt. In this case the liabilities generated by the inflow of foreign capital might grow at an unsustainable pace resulting in increased risk in the financial markets, and less funds allocated to countries with large trade deficits. At worst, the possibility to finance the deficits will be reduced - or will be small. Then there will be a gap between production capacity and demand, and the economic activities in these countries will decline - in the next round also causing damage in countries with trade surpluses.

The financial crisis has created a growing recognition that conventional monetary policy has responsibility for an effective monetary transmission mechanism, and that it has failed to account adequately for financial sector risk. However, what can be done?

\subsubsection{Economic Bubbles - A Challenger for the Central Bank?}

A bursting bubble started the financial crisis. A low interest rate over long time can contribute to house price bubble. To prevent a house price bubble the central bank can decide a higher interest rate that what follows from the inflation target and the production goal.

One main challenge related to the question above is that the central banks have few means available and many targets. Believers in a strict interpretation of Tinbergen separation principle will then ask if it is space for having a 
central bank's mandate to avoid house price bubbles. But it may also happen that policy to avoid economic bubbles and unemployment addresses two side of the same challenger.

What should be the focus in future monetary policy regarding the interaction between interest rate, household's loan /debt, house price bubble and the banks?

\subsubsection{Dynamic Inconsistent Behaviour}

If policy makers for example want to avoid a house bubble, the central bank should respond quickly to specific events. The central bank must then follow a discretionary policy approach. However, discretionary policies can be subject to dynamic inconsistency. A central bank may say it intends to raise interest rates indefinitely - to bring inflation under control. Authorities must always take into consideration the fact that new events impact the economy continually. The government can then be forced to change the interest rate from what was the original plan in order to protect the targets in economic policy.

A rule based policy can be more credible, because it is more transparent and easier to anticipate for the actors in the market. This is the background for the famous Kydland and Prescott (1977)" rules rather than discretion"state. Taylor (2007) claims that the financial crisis would have been less severe if Federal Funds rates the years before the financial crisis had been set according to Taylor rule, and the interest rate had not been pushed so low before the outbreak of financial crisis.

What should the compromise be between the central banks desire to behave with flexibility and transparency?

\subsubsection{Consequences of a Switching Interest Rate}

A consequence of flexible monetary policy and responding (quickly) to events and shocks is that the interest rates are switching up and down. This might make it difficult for investors to invest in the right projects (White, 2012), possibly resulting in bad investments and misallocation of resources. Assume a shock and that a adequate central bank respond is a credit expansion. The decreased interest rate increases desire to invest or consume. The price of the goods stimulated by the credit expansion will then increase. An example of a market which is significantly affected by a credit expansion and low interest rate is the property market. When the period of an artificially low interest rate is over and the pure market rate is back, an economic bubble may burst.

On this background we might ask, should it be restrictions and threshold values related to how the interest rate is pushed up and down?

\subsubsection{Coordinating Economic Policy - Or Independent Central Banks?}

Since the central banks have few means and at same time many targets, one may think that the central bank should work close to the government and increase the effectiveness of monetary policy by coordination it with governments' economic policy in other areas. On the other side, as long as monetary policy lay in the hands of elected politicians, they tend to exploit the instruments of the central bank in order to increase their chances of re-election. Sustainable real economic development will not be achieved by such decisions.

So what should be central bank's relationship to government and economic policy in other areas?

\section{How to Meet the Challenges?}

\subsection{How to Stimulate the Real Economy?}

\subsubsection{Forward Guidance of the Interest Rate - and Important Mean}

The new trend in monetary policy of guidance of the interest rate is based on the acknowledge that it is not so much by changing the very short term interest rate that the central banks can impact the decisions that matter most for the economy. What matter is rather by influencing expectations about the development of the short term interest rate in the future (Praet, 2013). Forward guidance is to communicating the short term interest rate path, with a confidence interval around it. The central bank can communicate different messages, and the message may depart from the usual one, in form and contain. The point is that the message will impact the economic actor's expectations and economic decisions - one or the other way - even if the short term interest rate is constant. By suggesting for example that the central bank will maintain a zero interest rate policy for long time in the future, this might be an instrument to stimulate the economy already at present, even if the short term interest is constant.

\subsubsection{Quantitative Easing}

Federal Reserve (in the U.S.), the Bank of Japan, the Bank of England and finely the European Central Bank (ECB) 
have after the financial crisis begun to pursue less conventional monetary policies, also known as "Quantitative Easing” (QE). The purpose in doing so has varied from one central bank to another (Fawley and Needly, 2013). To stimulate the real economy (U.S.), to impact inflation (U.S.), to reduce financial market distress (ECB). Therefore, QE in this paper will be commented also under other headings.

This section considers whether quantitative easing can stimulate the real economy. The technical relationship between QE and the real economy is as follows: When the central bank buys financial assets of longer maturity, the purchase of such assets (for example of long-term bonds) will increase their price and reduce the net yields from these assets. Reduced net yields will motivate private actors in these markets to look for other placement opportunities for their money. This may make it easier/cheaper for borrowers to have access to long term financing, and thereby the economy may be stimulated. In addition, some of their money will be used to buy shares. The rate of shares may increase and expectations about the future may change in a positive direction. All these elements will have the positive side effect of reducing unemployment and driving a more rapid return to the normal economic situation (Bernanke, 2010 and 2012). One interesting and important experience of the QE-motivated monetary policy is also that central bank in this way can target longer term rates - not only over-night and short term interest.

According to Fawley and Neely (2013) it is difficult to calculate the effects of the QE-programs on the real economy, partly because it is uncertain how the economic situation would have been without these policies (what is a normal challenger when doing research in economic policy). Garcia-Cicco (2011) says that very few studies have focused on more than one country simultaneously pursuing a QE inspired monetary policy approach. Thus, much of the research will ignore the negative cross-border spillovers following an QE-monetary policy approach (for more details see section 4.2 below).

Since it is difficult to demonstrate good empirical effects of the QE-program, the argument that printing money will fuel inflation has gained weight in the discussion of these programs. However, when unemployment and actual production are less than potential production, we should expect inflation to increase moderately. Moderate increases in inflation are also what are observed in countries and regions where the central bank has applied quantitative easing (Bernanke, 2012). One should also argue that increased inflation is not necessarily a bad thing in the present economic situation. A higher inflation rate will reduce the danger of deflation while at the same time reducing the real interest rate and thus stimulating consumption and investment (Eggertsson and Woodfjord (2003), Krugman (2010), Svensson, L.E.O. (2009) and Wyplosz (2010). Palley (2011) suggests that the central bank should target inflation so as to hit the minimum sustainable rate of unemployment, which he states is consistent to an inflation target over 2 percent yearly price increase (in U.S. probably between 3 and 5 percent).

The discussion above can be concluded in this way: QE-motivated monetary policy will from a theoretical point of view give monetary policy more power. However, since the economic down turn to day is not cyclical (but related to high state debt and national budget deficits in many countries), we must expect that QE- policy will have limited effects on present recession). One should also be concerned about the negative cross-border spillovers (see section 4.3).

\subsection{Financial Stability}

One important lesson of the financial crisis is: The monetary authorities cannot manage the economy with just interest rate and an inflation target (Palley, 2011). Outside the eyes of the authority it may be build up financial excesses. These excesses do not necessarily cause inflation and therefore fly under the radar screen of the monetary policy regime. But the imbalances in the financial sector from over-indebted households, firms and states, however, undermine the economy and force the economy to retard its activities and unemployment will increase. It is difficult to make monetary transmission mechanism more effective in short time.

Two important aspects of financial stability in a longer time term perspective are: (1) The bank sector should be more robust and get increased ability to stand against economy stagnates (Weber, 2011). (2) The banking sector and institutions in the capital market should reduce their involvement in speculation and financial gambling. An important answer to point (1) is to implement the recommendations in Basel Committee III - a comprehensive set of reform measures aimed to i) improve the banking sector's ability to absorb shocks, ii) improve the management and governance of the banks, and iii) strengthen banking transparency. Since the measures decided to make banking sector more robust are likely to have implications for cross-border competition between financial institutions, it is important that the measures decided and the implication of Basel III are a harmonized across countries.

What can be done to reduce the commercial banks' involvement in speculation and gambling? Throughout the financial crisis many banks had access to last resort central bank liquidity. The idea of last resort central bank 
liquidity is to help banks that are facing temporary funding stress. Insolvent banks should not be able to get access to this kind of assistance. Help arrangements which are not temporary may lead to more careless behavior, moral hazard, and the temptation for a bank to take on more risk. Therefore, a bank which does not succeed in making profits normally should go bankrupt, and only in special situations be saved by the central bank or government. Any change to this practice should send strong signals to temper bank speculation and financial gambling.

\subsection{Cross-Border Spillover}

Notice that countries following a QE strategy will depreciate their currencies. International competition will then increase and the trade deficit will be reduced. This is isolated a good thing. On the other hand, firms in countries with another monetary policy and restricted to print money will experience reduced competitiveness. The danger is that this cross-border spillover will force these last countries to react and consider countermeasures. The doctrine of free trade, from which we all benefit, may suffer. The best outcome would be acceptance by the international society of a necessary change in exchange rates so that trade imbalances over time can be reduced.

A part of the cross-border spillover is caused by most industrialized countries have floating exchange rates while many other countries pursue fixed or semi-fixed exchange rate regimes.

Eichengreen et. al.(2013) propose that a group of significant central banks should regularly meet and discuss and assess the implications of their policies for global economy and the expedience for global economy and financial stability. One may, however, claim that such matters little since such meetings have no control over the single central banks, many claims this would make little if any difference.

\subsection{Discretionary Monetary Policies - Versus Rules}

Taylor's rule prescribes how the central bank should balance the two key targets in conventional monetary policy, inflation target and a production target. The strength of the rule is that it makes monetary policy mechanical, and hence may prevent bad judgment by the staff of the central banks. On the other hand, Taylor's rule has the consequence that too much weight is put on short-term impacts and too little emphasis placed on long-term effects caused for example by changes in currency, development of house prices, increased private household debt etc.. Moreover, under Taylor's rule monetary policy depends on the coefficients in Taylor's equation and its restrictive assumption that they correctly reflect preferences of the citizen. It would seem to be poor judgment to ignore the impact that the interest rate has on the exchange rate in a small and open economy, while totally disregarding the influence of the interest rate on the development of housing prices and other economic bubbles. Therefore, those responsible for monetary policy should have a comprehensive and continuous overview of the macroeconomic conditions (the inflation rate, the production gap, the balance of payments, the public budget, the exchange rate, household debt, etc.). Based on this overview a central bank has the competency to takes its monetary policy decisions. This strategy requires - in addition to such a macroeconomic overview - flexibility and a discretionary approach to monetary policy. This flexibility is obtained at the expense of transparency (Sauer, 2010).

A summary of the above will be: Taylor's rule seems unlikely to perform better than a careful judgment of the risks to output growth and price stability. However, Taylor's rule is a rule of thumb, easy to investigate, and well worth taking into consideration. One aspect of the last statement is also that flexibility and switching interest rates involves costs (see section 4.5).

\subsection{Switching Interest Rates}

Conventional monetary policy assumes that by intervening in the monetary and financial system with economic competence and understanding, monetary policy makers should be able to stabilize the economy and improve the situation with less unemployment and increased economic outcome.

There will always be foreseen and unforeseen events occurring in the real world that might have a negative impact on the economy, and what monetary policy should protect against. However, frequently switching the interest rate up and down, sometime in long steps, involve costs. For example misallocation costs because of uncertain foundation for investments and the possibilities of economic bubbles. Even if discretionary monetary policy is recommended, one should therefore be careful when pushing the interest rate frequently and rapidly up and down (White, 2012).

Sometimes it is also necessary for the economy and markets to purge themselves of bad investments after a bubble bursts, and readjust through a reallocation of misplaced resources. If the central bank intervenes and responds according to conventional monetary policy, the result will be that the crisis and the painful process of purging will be prolonged (Gustafson and Randazzo (2010). 


\subsection{Monetary Policy-and House Price Bubbles}

Borio and White (2003) suggest that the central banks to prevent a housing price bubble - and banking crisis should decide a higher interest rate than what traditionally follows from the inflation target and the production gaps. There are several objections to changing monetary policy in this direction. One is that it is difficult, also for the central banks, to distinguish between house price increases that are real and price increases due to a bubble. If the central bank increases the interest rate because the bank believes that a housing price bubble is developing, and this belief is incorrect, then the decision to raise the interest rate may cause more damage than it prevents.

Another objection is that by increasing the interest rate, the central bank may disregard the main targets conventional monetary policy, namely to minimize the inflation gap and the production gap. Why? Economic theory tells us that we need one instrument for every independent target - the Tinbergen's hypothesis of the nature of policy choices (Tinbergen and Pollak, 1950). If the interest rate for example is set to avoid a housing price bubble, the central bank may be short of means to control inflation, full employment and other targets. Of course it may be important to avoid economic bubbles in the work to achieve full employment and obtain good resource utilization. In this case, any policy to avoid economic bubbles and unemployment really addresses two sides of the same issue. However, bursting economic bubbles is only one reason for unemployment, and probably not the most important one. Therefore, future monetary policy should have its main focus on total employment and not simply on housing price bubbles.

The conflict between the different targets, due to the fact that the central bank has few means available, can be reduced if the authority or government, to prevent housing price bubbles, resorts to means other than monetary policy or interest rates. One alternative would be to make housing investments more expensive by using the tax system. The government can, as far as housing investment is concerned, restrict the possibility of deducting interest payments from the tax settlements or introduce housing taxes.

The central bank can also reduce the conflict by letting the housing prices be part of the index which calculates the inflation rate. If house prices are increasing strongly and a housing price bubble is shaping, the calculated inflation rate will also be higher (depending on the weight the house prices have in the inflation index). If monetary policy for example is put on a "Taylor auto-pilot", the economic direction will be changed and the interest rate will be increased to find the new trade-off between the inflation gap and the production gap. An increased interest rate will damp down the demand for buying houses and in this way reduce the risk of a housing price bubble. It is likely that this would also happen if monetary policy was following a discretionary approach.

High interest in housing investments that push up housing prices may also be a response to low private individual rates of return on traditional forms of bank savings. In this case, the government should provide better alternatives, such as savings programs for youth and pension saving.

\subsection{Coordinating Economic Policy - In Conflict with the Independent Central Bank?}

The discussion about house price bubbles suggested that one could increase the effectiveness of monetary policy by coordinating it with government and other areas economic policy. What then with the principle in conventional monetary policy of central banks independent - and does this principle conflict the possibilities for coordination of economic policy. The answer is twofold, both clear communication and cooperation between the central bank and the government, and a independence central banks with ability to implement its own policy, are important. Two reasons why it is important to defend the central bank independence of authority and of different interest groups are the central bank's ability to respond professionally to (1) the government's fiscal policies and (2) the settlement of wage bargaining in private and public sector.

Consider first the question of coordinated wage bargaining. An independent central bank can be an important tool to prevent a high wage rate threatening the target of low or stable inflation and full employment. The central bank might respond to a settlement of the wage bargaining inconsistent with the national target of inflation and unemployment by tightening monetary policy. As a result, the wage negotiators will anticipate the response of the central bank, especially if the central bank makes clear statements about the consequences for monetary policy of too high wage settlements from a macroeconomic point of view(Hall, 1994). In this case workers might consider monetary policy as a instrument reducing their wage rate.

If monetary policy were under the control of an elected government, wage negotiators might be uncertain about whether the government will follow through on threats to deflate the economy in the wake of inflationary wage settlements, because they know that it will be influenced by a desire to remain popular enough to secure re-election (Hall, 1994). 
In a similar way an expansionary fiscal budget may be tempting when an election is approaching. However, when the government takes into consideration that the independent central bank will respond by tightening monetary policy, the government can be forced to dampen a too expansionary effect of the budget with negative impacts on inflation and unemployment (when they believe that voters will punish the government for the increased interest rate).

However, an independent central bank should not only respond, but also communicate (with the market and the politicians) and cooperate with the government. According to the guidelines of conventional monetary policy, the central bank should take into consideration consequences of interest decisions on inflation- and production gap, the exchange rate, household debt, the increase in housing prices, housing price bubbles and other factors. The room left for all these and other issues is rather small. To minimize the internal conflicts between these targets one must apply means in economic policy outside the monetary tool box. Considering housing prices and the threat of a housing price bubble, for instance, it might be necessary to think of using a tax tool box. This box is under the control of the government and is an example of an arena where the central bank and the government should talk and closely cooperate about targets and means. Another such area to talk together is financial stability.

\section{Conclusions}

Forward guidance of the interest rate and Quantitative Easing (QE) may give monetary policy more power when the short term nominal interest rate is close to zero lower bound. QE will also affect inflation. An increase in inflation rate will make the way out of current recession easier. It will reduce the danger of deflation and at same tome reduce the real interest rate, given the nominal rate, and in this way stimulate consumption and investment. The risk of a too high inflation in an economy where the unemployment rate is too high, is small.

The current recession is a consequence of excessive debt in private and public sector in several countries. Because public sector and the households need time to pay down debts and rebuild savings, however, time will also be needed to emerge from the present recession. Since the economic downturn today is not cyclical, standard monetary policy as well as non-standard monetary policy (QE) will have limited effects on the present recession.

An important lesson from financial crisis is that imbalances in the financial sector and high debt in private and public sector may fly under the inflation radar screen in conventional monetary policy. When no red light is lighting, the imbalances may undermine the economy. Monetary policy in future should therefore target price stability, the production target, avoiding house price bubbles, and supporting financial stability etc.

The interest rate cannot at the same time serve the inflation target, the production target, avoidance of an economic bubble, and eventually other independent targets. The Tinbergen rule tells us that we need one instrument for every independent target. If the interest rate for example is set to avoid a housing price bubble, the central bank may be short of means to control inflation and full employment. Therefore, future monetary policy should have its main focus on inflation, total employment, financial stability, and not simply on housing price bubbles.

As a consequence, the central bank and the government should communicate and cooperate about monetary target and means. From internal discussion it might come up an intentional agreement that a house price bubbles could /should be prevented by also other means than monetary policy and interest rates. One alternative would be to resort to the tax system which the government is responsible for. The government can also fight house price bubbles by restricting the possibility of deducting interest payments from tax settlements.

Taylor's rule affords a maximum of transparency, but is unlikely to perform better than a flexible monetary policy when a central bank's carefully consideration of inflation target, production gap, other possible targets, and the means the bank has available (the interest rate). On the other side, Taylor's rule formally is a rule of thumb, but easy to calculate and should be used to qualify the interest rate decision.

Flexibility monetary policy and switching the interest rate frequently up and down, perhaps with long steps, may incur some costs, such as misallocations and the possibility of economic bubbles. One should therefore be careful when we push the interest rate rapidly up and down in big jumps.

An independent central bank is still an important choice, especially to respond to a too high wage rate settlement making it difficult to obtain price stability and to respond to too expansive financial policy.

This paper suggests that we should use market mechanisms to a higher degree in the bank market. Through financial crisis, many insolvent banks were helped by governments. One good effect of a new practice would be that it makes clear to lending institutions that they are responsible and must consider the risk in relation to their investments. 


\section{References}

Barro, R., J., \& D. B. Gorden. (1983). Rules, Discretion and Reputation in a Model of Monetary Policy. Working Paper No. 1079 National Bureau of Economic Research, 1050 Massachusetts Avenue Cambridge MA 02138, February 1983.

Basel III. (2013). Retrieved 2 October from http://en.wikipedia.org/wiki/Basel_III

Bean, C., Paustiann, M., Penalver A., \& Taylor T. (2010). Monetary Policy after the Fall. Paper presented at the Federal Reserve Bank of Kansas City, Economic Symposium - 2010, Jackson Hole, Wyoming, N.Y. 26-28, August, 2010.

Bernanke B. (2010). Monetary Policy and Housing Bubbles. Speech at the annual meeting of the American Economic Association: Atlanta, Georgia.

Bernanke B. (2012). Monetary Policy since the Onset of the Crisis. Speech at the Federal Reserve Bank of Kansas City Economic Symposium, Jackson Hole, Wyoming, August 31, 2012.

Blanchard, O. (2009). The Crisis: Basic Mechanisms, and Appropriate Policies. IMF Working Paper, 09/80, International Monetary Fund. http://dx.doi.org/10.5089/9781451872279.001

Blanchard, O.J., Dell'Ariccia, G., \& Mauro. P. (2010). Rethinking Macroeconomic Policy. Journal of money, credit and banking, 42, 199-215. IMF Staff Position Note. http://dx.doi.org/10.1111/j.1538-4616.2010.00334.x

Borio, C., \& White W. (2003). Whither Monetary and Financial Stability? The Implications of Evolving Policy Regimes. BIS Working Papers, No 147.

Brunnermeier M. K. (2009). Deciphering the Liquidity and Credit Crunch 2007-2008. Journal of Economic Perspectives, 23(1), 77-100. http://dx.doi.org/10.1257/jep.23.1.77

Caselnuovo, E., S. Nicolette-Altimarian \& D. Rodrigueez-Palenzuela. (2003). Definition of Price Stability. European Central Bank Working Paper NO. 273.

Claessens, S., Kose A., \& Terrones M. (2008). What Happens during Recessions, Crunches, and Busts? Economic Policy. Forthy-Ninth Panel Meeting, Brussels 24-25 April 2009.

Eggertsson, G. B., \& Woodford M. (2003). The Zero Bound on Interest Rates and Optimal Monetary Policy. Brookings Papers on Economic Activity, 1:2003.

Eichengreen, Barry, M. El-Erian, A. Fraga, T. Ito, J. Pisani-Ferry, E. Prasad, R. Rajan \& M. Ramos. (2013). Rethinking Central Banking. Committee on International Economic Policy and Reform.

Fawley, B. W., \& C. J. Neely. (2013). Four Stories of Quantitative Easing. Federal Reserve Bank of St. Louis, 95(1), 2013.

Garcia-Cicco, J. (2011). On the Quantitative Effects of Unconventional MonetaryPolicies in Small Open Economies. International Journal of Central Banking, 7(1), 53-115.

Greenspan, A. (1989). Statement by Chairman, Board of Governors of tha Federal Reserve System before the Committee on Banking, Finance and Urban Affairs, US. House of Representatives. January 24, 1989, Federal Reserve Bulletin, March 1989: 139-42.

Gustavson, M., \& Randazzo A. (2010). The Hayek Rule: A new Monetary policy Framework for the $21^{\text {st }}$ Century Reason Foundation, Policy Study 389, November $9^{\text {th }} 2010$.

Hall, Peter, A. (1994). Central Bank Independence and Coordinated Wage Bargaining: Their Interaction in Germany and Europe. Program for the Study of Germany and Europe, Working Paper Series \# 4.4,1994.

Keynes, I. M. (1936). The General Theory of Employment, Interest and Money, Volume VII of the Collected Writings of John Maynard Keynes (1973), Macmillan, London.

Krugman, Paul. (2010). Why Is Deflation Bad. New York Times, August 2, 2010.

Kydland, F.E., \& Prescott E. (1977). Rules Rather Than Discretion: The Inconsistency of Optimal Plans. Journal of Political Economic, 85(3), 73-91. http://dx.doi.org/10.1086/260580

Pally, Thomas I. (2011). Monetary policy and Central banking after the Crisis: The Implications of Rethinking Macroeconomy Theory. IMK Macroeconomic Policy Institute, Working Paper. 8/2011.

Phelps, E. (1972). Inflation Policy and Unemployment Theory. Macmillan, London. 
Praet, P. (2013). Forward Guidance and the ECB. Retrieved 2 October 2013 from http://www.voxeu.org/article/forward-guidance-and-ecb

Reinhart, C. M., \& Rogoff, K. (2009). This Time is Different: Eight Centuries of financial folly. Central bank review, 12(January), 2009.

Richard, S. (2013). Why negative interest rates would make the UK economy worse rather than better, Mindful Money. The social news and knowledge network for the investment community, Sept 30, 2013.

Sauer, S. (2010). Discretion Rather than Rules? When is Discretionary Policy Making Better than the Timeless Perspective? International Journal of Central Banking, 6(2), June 2010.

Summers, L. (1991). How Should Long-Term Monetary Policy be Determined? Journal of Money Credit and Banking, 123, 625-631. http://dx.doi.org/10.2307/1992697

Svensson, L. E. O. (2009). Flexible Inflation Targeting: Lessons from the Financial Crisis. De Nederlandsche Bank, 21 September.

Taylor, J.B. (1993). Discretion versus Policy Rules in Practice. Carnegie-Rochester Conference Series on Public Policy, 39, 195-214. http://dx.doi.org/10.1016/0167-2231(93)90009-L

Taylor, J.B. (1999). Monetary Policy Rules. Chicago: University of Chicago Press. http://dx.doi.org/10.7208/chicago/9780226791265.001.0001

Taylor, J.B. (2007). Housing and Monetary Policy. Working Papers Series 13682. Cambridge Mass.: National Bureau of Economic Research, December 2007.

Tindbergen, J., \& J. J. Pollak. (1950). The Dynamics of Business Cycles. Chicago: University of Chicago Press.

Vickrey, W. (1955). Stability Through Inflation. In K.Kurihara (ed), Post-Keynesian Economics, George Allan and Unwin Ltd., London.

Weber, Axel A. (2011). Challenges for Monetary Policy in the European Monetary Union, Federal Reserve Bank of St. Louis, 93(4), 2011.

White, W.R. (2012). Ultra Easy Monetary Policy and the Law of Unintended Consequences. Federal Reserve Bank of Dallas, Globalization and Monetary Policy Institute, Working Bank of Dallas, Globalization and Monetary Policy Institute, Working Paper No 126, August 2012.

Wyplosz, C. (2010). Monetary Implications of the Crisis: Dominance at Stake. Nordic Economic Policy Review, 1, 171-197. 